\title{
Reconsidering Rationales for Local Self-Government - Impacts of Contemporary Changes in Local Decision- Making
}

\author{
ROLV LYNGSTAD
}

\begin{abstract}
This paper discusses two contemporary trends in local decision-making. Firstly, there seems to be more centralised decisionmaking today than before in important policy fields such as welfare policy. Secondly, informal governance processes outside formal government structures open up for a substantial influence from nonelected political actors. The paper asserts that there is a connection between the trends, and argues that the centralisation tendencies in welfare issues might affect and encourage governance processes in other local policy arenas. These policy fields are mainly within the socalled 'developmental policies' that often facilitate more networking and partnership activities in 'grey areas' between the public, private and civil sectors in collective problem solving. Accordingly, more attention should be given to policy fields where governance networks operate, and the implications for revitalising democratic political participation should be studied. The paper concludes that the well-established rationales for local self-government and local democracy need to be reconsidered by taking into account these new decision-making structures.
\end{abstract}

KEYWORDS: • local self-government $\bullet$ rationales $\bullet$ welfare policy • developmental policy $\bullet$ governance

Correspondence Address: Rolv Lyngstad, Ph. D., Faculty of Social Science, Bodø University Colege, N-8049 Bodø, Norway, e-mail: rolv.lyngstad@hibo.no. 


\section{Introduction}

Like the Scandinavian countries, many unitary states are characterised by a strong public sector with a great responsibility for welfare policies (health care, social service, education, etc), and these policy fields have traditionally been delegated to local governments for implementation and decision-making. Recent developments, however, seem to indicate more centralised decision-making, especially with regard to welfare policies. National agencies and politicians interfere with the way local governments and decision-makers execute their responsibilities. Thus, local discretion is decreasing and the scope of action for local politicians is lessening (Østerud et. al. 2003, Fimreite et. al., 2007). In parallel with this trend, another development in local decision-making is occurring. Networking and partnership activities between elected and non-elected actors operating outside formal government structures and institutions are flourishing and growing (Pierre \& Peters, 2000; Sørensen \& Tørfing, 2009b). Thus, more and more decision-making is affected by the political activity from many local actors. There seems to be a development 'from government to governance' where informal governance processes involving many local actors are participating in decision-making processes. Both trends seem to "hollow out" the role of local politicians in public decision-making. ${ }^{1}$

After exploring these two contemporary trends by relating them to different dimensions of local autonomy and different rationales for local decision-making, a question arises: Why should local actors and decision-makers bother to engage in local politics if the scope of action is reduced by central authority interference? I assert that the trends are interconnected in a way where the decreasing scope of action for local politicians in welfare policies paves the way for vitalisation of local politics through governance processes in developmental policies. This paper argues that in order to understand this, rationales for local determination and decision-making must be reconsidered by explicitly making a difference between local self-government and local democracy. Democratic and instrumental arguments in favour of local decision-making are explored and related to vertical and horizontal dimensions of autonomy. I finally conclude that justifications for local government and decision-making need to be complemented in a way that take the focus away from welfare issues towards paying more attention to economic and development policies.

\section{Changing Rationales for Local Self-Government?}

The different justifications for local self-government outlined below are an important backdrop for understanding the contemporary changes in local government politics and policies. The rationales for local self-government can be discussed in relation to what kind of citizen rights we accentuate (Marshall, 1964). Democratic rationales for local decision-making emphasise the role of citizens as 
a citoyen and not only as a bourgeois in society. Liberty is a core value and political rights should be executed within the polity where collective life is "governed by socially validated and individually internalised rules, norms, and understandings."(Olsen, 2009: 22) Inhabitants are conceived as political humans, and society should facilitate political activities, thereby building a viable local community where people's engagement has an impact on decision-making and political life. Decentralisation and devolution in decision-making will make the polity more transparent and accountable.

This line of argumentation focuses on the input side of decision-making, and is concerned with how the citizen political rights can be facilitated and modified. It is truly democratic, emphasising the right for everyone to participate in decisionmaking that affects themselves and the community they live in. The citizens in municipalities should be free to decide for themselves to follow their beliefs and pursue their ideas as long as the decisions do not harm anyone else. The participation in decision-making is considered as a good in itself. This liberty value favouring local self-government has a solid position in Scandinavian political systems. The argument is that local decision-making shall ensure democratic rights and thereby legitimate public policy by educating citizens to be engaged in politics as well (see Sharp, 1970). The democratic and freedom argument (with important educational function) in favour of local government is rooted in a long liberal tradition (see, for instance, Mill, 1975). There are, however, contemporary scholars who are critical of liberal theories because they insufficiently establish a justification for local government based on ethical grounds "as an independent entity in its own right" (Chandler, 2008: 355). Many justifications, Chandler argues, represent "the triumph of expediency over ethics" (Chandler 2008: 355) ${ }^{2}$.

This expediential justification for local discretion in policy-making in fact represents the other main line of argument. This is a kind of an instrumental argument emphasising the need to improve public policy. Contrary to the democratic argument, this instrumental argument, as argued above, focuses on the output side of the political decision-making process. It is an argument where the deliverance of public policy in general and welfare policy are highlighted more specifically. According to this perspective, the citizens are primarily users of public goods, and local decision-making is supposed to be a remedy for improving the quality of public policy. The citizens' social rights are in focus (focusing on the bourgeois role of inhabitants), and the criterion for political success is the fulfilment of public goods. To succeed, however, with a relevant and adequate public policy, it is always useful, and sometimes necessary, to know the local problem structure, conditions, culture, traditions, and values. Policy-makers, living far away from the locality where the policies will be implemented, will probably not have the same knowledge. Therefore, there will be less possibility to succeed in targeting the real issues and problems. Input and decision-making based on 
local knowledge and competence are regarded as a necessity to ensure the quality of public policy at the local level. Especially in the realm of the welfare state, the need for 'tailor sewing' based on local circumstances has always been the predominant argument for influencing local decision-making. The principle of subsidiarity to ensure relevance and adequacy in performing public welfare policy is a train of thought in all the Scandinavian welfare states.

It is crucial to notice that both the democratic line of argument (grounded in freedom and participation values) and the instrumental line of argument (grounded in efficiency and effectiveness values) conclude with a certain amount of discretion to local decision-makers. In fact, since the origin of local government in the Scandinavian countries, these rationales have been predominant. This is in particular the case with respect to education, welfare, and social services. Local knowledge is regarded to be a prerequisite for a well-functioning welfare policy. Therefore, some find it more appropriate to talk about a welfare municipality instead of the more common welfare state in relation to welfare services in society (Grønlie 1987) ${ }^{3}$. To illustrate the significance of welfare issues (including education and kindergartens), the figures for 2007 show that 78 percent of total local government expenditures in Sweden ${ }^{4}$ are used in these policy arenas, and the corresponding figure for Norway ${ }^{5}$ is 76 percent. Bearing in mind that the public sector in both countries is large and that the municipal level by far is the most cost-demanding layer of public administration, these figures utterly emphasise the local government role in the welfare state, and thus accentuate both democratic and instrumental justifications for local self-government.

These arguments in favour of local decision-making are, however, challenged by other developments favouring more centralised political processes. The focus on the equality value is most important in public policy. Especially the Scandinavian welfare states are characterised by a high level of equality in society. This is also true when it comes to services and welfare benefits. A comprehensive social security system, institutionalised social rights, universalism, and the anticipation that the state shall ensure equality among inhabitants with regard to public goods are universally accepted and are the hallmarks in all countries (Kosonen 2001). Thus, central authorities are in charge of equalizing policies. A challenge occurs, however, when local governments and authorities use their autonomy, and, according to the principle of decentralisation and devolution, actually prioritise their available resources differently. The result can be that the quality of welfare and social services differs a lot between inhabitants and municipalities. This being the case, national and local decision-makers are confronted with a dilemma, and have to consider two "worthy" values in public decision-making, i.e., the value of 'national equality in service delivery' and the value of 'local freedom to decide according to local preconditions'. The centralisation trend outlined below seems to give priority to the value of equality. Along with the trend in favour of expediency 
in decision-making, contemporary developments in local politics and policies will probably modify the rationales for local self-government.

\section{Is Centralisation Threatening the Vertical Dimension of Local Autonomy?}

Autonomy is a relational concept and it usually materialises in the decisionmaking process. The degree of autonomy in decision-making will depend on the formal competence and real discretion given to the actors participating in the process. Local government autonomy will vary with legal, economic, and organisational frames decided by central authorities. We usually refer to these delimiting frames when asserting that local autonomy is confined. Local selfgovernment is about this vertical dimension of the concept of autonomy. Selfgovernment implies that decision-makers are located in the municipality and that the scope of political action is substantial. The vertical dimension of autonomy is therefore about power relations organised in a hierarchy where parliament and central government are at the top, and the municipality with its governing institutions is at the bottom of the hierarchy acting autonomously without interference from high-level decision-making. Two variables affect the degree of vertical autonomy at the local level: Firstly, the range of functions (including the number of policy fields) ascribed to local authorities. Secondly, the degree of discretion to conduct a policy without any interference from central authorities. Dichotomisation of the variables gives us the following table with respect to vertical autonomy:

Table: Variables affecting vertical autonomy in municipalities

\begin{tabular}{|c|l|c|c|}
\hline \multicolumn{4}{|c|}{ Number of policy fields } \\
\hline \multirow{3}{*}{$\begin{array}{c}\text { Degree of } \\
\text { discretion }\end{array}$} & Restricted & 1 & Many \\
\cline { 2 - 4 } & Extensive & 3 & 4 \\
\hline
\end{tabular}

The categories are ideal types useful to study the differences between local governments in different political systems. The distinctions between the categories are diffuse in most countries because the dichotomisation of the variables represents a simplification ${ }^{6}$. The first category represents the narrowest form of local self-government. The local decision-makers have responsibility for few policy fields, and the central authority confines the local policy in a strict way. The scope of action is poor. Category 2 represents a situation where formal responsibility is given to municipalities in a wide range of policy fields, but the national government intervenes significantly to ensure that the policy outcome is in accordance with the central values and norms. The discretion is rather low. In category 3, local governments have few tasks to accomplish, but on the other hand, the discretion to handle the tasks is comprehensive. Category 4 (extensive discretion over many policy fields) represents municipalities with many tasks to 
accomplish, and their competence to decide on their own terms (without any interference from the state) is great.

Researchers, politicians and bureaucrats in the Scandinavian countries discuss about which category contemporary municipalities fit into. Scandinavian local governments have general competence. Even though the Scandinavian countries are unitary states, many policy fields are relatively decentralised due to the democratic and instrumental arguments mentioned above. During the last decades, there has been a move towards the right column in the table. The question is whether category 2 or 4 is most appropriate to describe the municipalities. Some argue that local governments, particularly in Norway, are mostly loyal implementers of the nationally designed policy in accordance with the expediential justification for local self-government (Baldersheim et. al., 1997; Vabo, 1998; Hansen, 2001; Sellers \& Lidstrøm, 2007). According to this argument, Norway is probably more "traditional public administration-oriented" than other Scandinavian countries (Hansen, 2001: 114), even though Norway is also affected by new public management ideas. Some argue, for instance, that due to the influence of NPM, Norway experiences a large diversity in organisational structures and looser relationship between central and local welfare interests and professions (less segmentation). This trend makes it more difficult for national authorities to implement nationally designed policies at the local level. There is less coherence in understanding and there are fewer channels for political influence (Fimreite et. al. 2007). Because of this, the overall "conclusion seems to be that the central government has increased its control over local authorities, leaving fewer discretionary options to local decision makers" (Jakobsen, 2009: 223). A kind of administrative decentralisation (municipalities have the responsibility for implementing the policies) and political centralisation (central level reduces the local discretion) seem to be parallel processes. This appears to be the case within the welfare sector in particular. According to Fimreite et. al.,

“The central institutions' confidence in municipal actors' ability to implement national policies within the main welfare sectors is reduced. As a response, central government is tightening its control over local government by introducing measures like management by objectives, standardisation, more detailed reporting systems, and individual rights legislation. Thus, the room for diversity and variation on the local level regarding, for instance, service production is much narrower now than it has traditionally been."(Fimreite et. al., 2007: 165)

Much research confirms this observation (see, for instance, Hansen et. Al. 2000, Fimreite et. al. 2002, Østerud et. al., 2003), and there are many examples of contemporary political practice and debates supporting this observation. For instance, in the national election campaign in Norway in autumn 2009, the focus 
was on the following issues: the amount of cash benefits for people dependant on welfare, the regulation of the ratio between teachers and students in schools, individual rights given to elderly people, and to what extent fixed charges, tuitions, and fee-for-service recipients can be charged by local government. The deliberation on these issues indicates very well the willingness of many political parties to reduce discretion and scope of action for local decision-makers, especially if media focus on large inequalities in service deliverance between municipalities.

The researchers of the relationship between local and central government seem to agree that there is a tendency towards more central interference in local priorities. This is also the case with respect to the traditional welfare and education sectors. Thus, the vertical autonomy for local decision-makers is shrinking. It is not because local level of policy-making has lost responsibility for the main welfare issues, but because the degree of discretion has been restricted by taking various limiting measures, and by actively using "sticks and carrots" to make sure that national standards are met in welfare delivery. Local government has become "an instrument for more ambitious state policies aiming at equalizing welfare." (Østerrud \& Selle, 2006:4) Therefore, it is probably right to conclude that at least Norway fits into category 2 in the table above ${ }^{7}$, and the centralisation tendency in traditional local policy fields seems to challenge local self-governance and autonomy. When the degree of discretion shrinks, the instrumental argument favouring tailoring in local service deliverance will lose its significance in the argumentation for local self-governance. When turning to the governance trend in local decision-making, the focus will be on the democratic line of argument for local governance in public policy.

\section{Is Governance Threatening Local Democracy?}

As stated in the introduction, informal governance processes characterised by networking and partnership activities are other important features within contemporary local decision-making in addition to the centralisation tendency. Conventional wisdom seems to agree that we are moving away from 'government' to 'governance', even though some scholars argue that "we should rather see governance as a 'new perspective on an emerging reality' (Sørensen \& Tørfing, 2009b: 2). While the centralisation issue is primarily about local self-government and related to vertical autonomy, the governance issue should be discussed in relation to local democracy and the horizontal dimension of local autonomy. Local self-government is about the competence given to local decision-makers, while local democracy and the horizontal dimension of autonomy are about actors who have power to decide over political issues in a municipality. The horizontal dimension is therefore about who actually participates in the local decisionmaking process, and about how actors with no democratic mandate participate in the decision-making process. It also refers to whether they have a decisive impact 
on the political outcome. If the latter is the case, the horizontal autonomy of elected politicians is weak, and democratic implications need to be investigated.

However, the term "democracy" is defined and understood in many ways. In its broadest sense, democracy is about a government of, by and for the people. Democracy is usually characterised by a political system that allows the citizens to participate in political decision-making by electing representatives to political bodies. In most modern societies, the democratic mandate of the local level decision makers is based on local elections. In this indirect and representative democracy, political decision-making is supposed to take place through a chain from elections to decisions by using elected representatives, often called the "parliamentary chain of governance" (Olsen, 1978). ${ }^{8}$

In most countries, this ideal constitutional and numerical model of decisionmaking is rather inadequate to describe real decision-making processes in local communities as well as at the national level. The influential urban scholar Clarence Stone puts it this way: "Campaigns and elections are only the tip of the political iceberg. Beneath the water line of overt political activity, citizens interact with official state agents, and with one another in many ways" (Stone, 2009: 268). Therefore, to 'grasp the reality', power structures connected to the activity of interest groups, and corporations in the allocation of public goods must be considered (Rokkan, 1966) as well as 'the privileged position' of business (Lindblom, 1977). The importance of constitutions, legal systems and government structures is questioned by the public choice theory (Thiebout, 1956), new institutionalism (March \& Olsen, 1989), and (neo-) Marxist analysis (Castell, 1978; Pickvance, 1995). At the local level, the community power debate between elitists and pluralists in the USA in the 1950s and 60s (Hunter, 1953; Polsby, 1960; Dahl, 1961), the concept of growth coalitions or growth machines (Molotch, 1976; Logan \& Molotch, 1987), the need for and focus on 'developmental policies' (Peterson, 1981), and urban regime theory, systemic/command power, and governing coalition concepts (Stone, 1980, 1989, 1993; Elkin, 1985, 1987) illustrate the complexity of political decision-making. They confirm that the parliamentary chain of governance needs a supplementary analysis to grasp the real power structures ${ }^{9}$. These analyses and discourses are most common in the US setting, but they are also relevant to studying European local policy and politics. This is especially the case with an urban regime analysis, even though there are scholars who argue that the theory is under-theorised and that it depends too much on the cases from the U.S. context (Pierre, 2005).

In a European context, concepts such as governance, networking, and partnership seem to be more predominant in the analysis of political decision-making at both central and local levels (Rhodes, 1997; Bogason, 2000; John, 2001; Pierre, 1998, 2000, 2005; Pierre \& Peters, 2000). Especially the 'governance' concept has gained frequent use, and the resemblance to the concepts used in regime analysis 
is striking. 'Governance' "shares many of the defining characteristics of urban regime analysis such as governing arrangements that include actors beyond the formal institutions of government, and the need to mobilise resources to achieve the capacity to act" (Mossberger, 2009: 48). Mossberger asserts, however, that scholars using regime analysis in comparative studies "have increasingly turned toward the broader, but related idea of governance" (Mossberger, 2009: 50). Therefore, the concept of 'governance' is of special interest because it has a growing popularity in the political science literature, and it is used within subfields such as public administration, international relations, and comparative politics (Kjær, 2004). 'Governance' as a concept often indicates the development away from decision-making in formal government structures towards more decision-making as a result of informal governance processes. This is also the case at the municipality level, and there seems to be a move from local government to community governance characterised by a greater involvement of non-state actors in decision-making. According to Rhodes, "governance refers to self-organising, inter-organisational networks characterised by interdependence, resource exchange, game rules, and significant autonomy from the state" (Rhodes, 1997: $15)$, while 'government' usually refers to more formal institutions and decisionmaking structures. Sørensen and Tørfing include an element of instrumentalism in the definition and "define governance as the complex process through which a plurality of social and political actors with diverging interests interact in order to formulate, promote and achieve common objectives by means of mobilising, exchanging and deploying a diversity of ideas, rules and resources" (Sørensen and Tørfing, 2009b: 5). The literature also makes a difference between 'governance' and 'governance network' ${ }^{10}$. Klijn and Skelcher (2007), for example, describing the latter as "public policy-making and implementation through a web of relationships between government, business and civil society actors", and the actors involved are "concerned with governance, i.e., the articulation, resolution, and realisation of public values in society" (Klijn \& Skelcher, 2007: 587). Sørensen and Tørfing argue that "the central decision makers to an increasing extent view governance network as an efficient and legitimate mechanism of governance" (Sørensen \& Tørfing, 2005: 199).

In the discourse about the use and impact of increasing governance networks, both input-oriented legitimacy and output-oriented legitimacy (Scharpf 199), efficiency, transparency, accountability, and democracy have been in focus. According to Sørensen and Tørfing, governance network theorists "tend to agree that governance networks suffer from the absence of open competition, legitimacy problems, and the lack of transparency, publicity and accountability" (Sørensen \& Tørfing, 2005: 201). Kjær asserts that "the democratic problem is that networks usually only serve some interests, and not the aggregate interest, i.e., the common will” (Kjær, 2004: 55), and she criticises governance theory because it fails to focus on issues of power, conflict and interest (Kjær, 2009). Likewise, Andersen and van Kempen (2001) argue that the democratic problem arises if the processes 
are exclusive, the political outcome is not in the interest of the public, and the accountability of decision-makers is weak. In their book about urban governance in Europe, they conclude that informal governance processes should not replace formal government structures in local decision-making because "governance does not exercise power in the interest of the public, but in the interest of the participants of the partnership, or at least in the interest of one or a few of the partners. Consequently, it is important to subordinate governance to representative democracy.” (Andersen \& Van Kempen, 2001: 12)

It is therefore important to ask "to whom the networks are accountable, and how a representative democracy works in the context of an increasing influence of public-private partnerships, involvement of voluntary organisations, and intergovernmental relations." (Kjær, 2004: 49). Sørensen and Tørfing suppose that the democratic anchorage is sufficiently provided "when a governance network is controlled by democratically elected politicians, represents the membership basis of participating groups and organisations, is accountable to the territorially defined citizenry, and follows the democratic rules specified by a particular grammar of conduct" (Sørensen \& Tørfing, 2005: 222). To ensure that governance networks function according to these principles, Sørensen and Tørfing use the concept of metagovernance (the governance of governance networks), and argue that various metagovernance tools should be employed (Sørensen \& Tørfing, 2009a). The main challenge, however, seems to be the democratic accountability problem (Papadopoulos, 2007, 2009). Even though relatively few studies address questions of democracy and legitimacy (KohlerKoch, 2006), Papadoupolos (2009) with a reference to a famous phrase of Rokkan (1966) that the growth of governance networks in political decision-making seems to imply that votes count less and resources decide more than before. Metagovernance tools may be useful, but "to subordinate governance to representative democracy" (Andersen \& Kempen, 2001: 12) may still be necessary to ensure democratic accountability.

Much of the literature reviewed in the paragraph above analyses the governance trends at the general and local levels. This also seems to be the position of the Norwegian 'Power and Democracy 'project. It was a five-year state-funded study finished in August 2003 (Østerud et al., 2003) ${ }^{11}$. The researchers claim that democracy as a chain from elections to decisions has weakened in Norway during the last decades. This comes true also with respect to local level decision-making. 'The political purchasing power of the ballot is diminishing' as the researchers put it (my translation) (Haugsvær 2003). At the local level, this is mainly due to judicialisation of welfare benefits and services on the one hand (state interference as outlined in the latter paragraph) and a tendency to give governance networks more problem-solving capacity in dealing with collective issues on the other. The result may be reduced power for locally elected politicians. 
The governance analysis is mainly concerned with the output side of political decision-making, and the review of various literature affirms that contemporary governance processes may raise some potential democratic problems, and thus questioning democratic rationales for local self-governance. The challenge is to make this form of decision-making transparent and accessible to all citizens, and to ensure that it is not a prerogative or an exclusive option for local elites.

\section{Why is More 'Governance' Occurring?}

After reviewing four books ${ }^{12}$ on governance, Christopher Ansell concludes that "these volumes suggest that governance networks are necessary for solving problems, and they are here to stay, but they also challenge some of our basic democratic commitments." (Ansell, 2008: 471). Much of the governance literature seems to have the same conclusion and a further deliberation about "why more governance' would be of interest. In the aftermath of the neo-liberal doctrine in economy which argues for more market and less state, the political climate for more involvement of private actors in decision-making in general and particularly in the public sector was good. In public administration and public policy, slogans like "less rowing and more steering" - often understood as "less government and more governance" - paved the way for New Public Management reforms (Christensen \& Lægreid, 2007). The focus has been on efficiency in public management and on how to improve and accomplish collective goods. Especially activities in the "grey areas" between the public, private and civil sectors have been of interest. Potentials and problems - related to different frameworks characterising activities in the sectors - have been in focus. Despite these differences there seems to be a common understanding that more collaboration between the sectors is necessary to produce public goods in an efficient way. Thus, more governance and partnership interactions are influenced by NPMinspired ideas, and activities unfold within the areas where the borders between 1) political decisions within public sector, 2) market-related rationales, and 3) civil society potentials are diffuse. This aspect certainly accommodates collaboration and co-operation between the state and non-state actors in solving collective problems. The "grey areas" are, so to speak, the areas of deployment for governance network activities.

The focus on the expediential side of governance and tracing the influence of neoliberal and NPM ideas seem to be the hegemonic perception of the contemporary governance analysis, and there is no reason to doubt this. However, I will argue that both the centralisation tendency in politics and the local government revenue structure are possible in complementary grounds for more governance in municipalities. In the paragraphs below, I will clarify this argument.

In both the common political debate and political science, there has been an important discourse about what type of policy fields should be delegated to the 
local level of decision-making, and what type of policy fields should be national responsibility. Many white papers have been written, and with respect to Norway, the conclusion seems to be that the local level (and especially the regional level) should have a larger responsibility for developmental policies. In political science, much of the literature builds on Lowi's typology of policy fields (Lowi, 1964), and Paul E. Peterson's prize winning book "City Limits" (Peterson, 1981) has had a great influence ${ }^{13}$. He uses the concepts of 'redistributive, distributive, and developmental policies', arguing that central governments should take care of redistributive policies while local governments are inclined to and should take care of economically motivated developmental policies.

However, the issue 'what level of political decision-making should have responsibility for policy fields' must also be understood in relation to the relative discretion given to decision-makers. I will argue that the interference from national authorities in one policy field (welfare sector), where the scope of action for local governments has traditionally been comprehensive, has some implications for engagement in other policy arenas. Fewer policy options in one area may pave the way for more activity and interest in another area. The available "policy space" will be filled, so to speak. The reason for this seems to be obvious. Politicians need to prove that their effort and engagement as locally elected representatives of people have an impact on people's lives, and ambitious local politicians want to be more than just loyal implementers of national government policy. They regard the mandate they got from the local election as more decisive for decision-making than centrally conceived enforcements. This attitude reflects the perception of local government as an autonomous political institution in its own rights (Chandler, 2008) and not only as an integrated part of the welfare state (Kjellberg, 1991). Therefore, local politicians will search for policy fields where their autonomy is real and their decisions have a decisive impact on the political outcome in a municipality. Such an assessment falls quite well within the supposition in 'The Norwegian Power and Democracy' document where it is stated that "if we look a bit ahead, it is therefore not unlikely that the local government activity is restricted to the areas in which there are genuine local concerns, e.g., cultural affairs, planning, building and zoning, some areas of communications, and transport." (Østerrud \& Selle, 2006: 4)

Accordingly, the reduced power of local politicians to pursue their own policy in traditional welfare areas does not necessarily make the local level of political decision-making irrelevant and uninteresting. Actually, new policy fields seem to be activated and developed, and a diminishing scope of action in welfare areas may form the basis of networking and partnerships through governance processes in other policy fields. These new fields are related to the local government role as a local development agent. Economic and cultural policies are good examples of policy fields where central governments do not interfere in a restrictive way. Therefore, it could be more attractive for local politicians and other local actors to 
engage in these policies. To put it another way, in the interaction between public, private and civil sectors there is a field of action particularly suitable for innovation and economic development. These policy fields, frequently located in grey areas, facilitate networking, partnership building, and informal governance processes, and they may substitute political activities in the traditionally important distributive and redistributive fields of policies ${ }^{14}$.

Another explanation of the growth of governance networks can be more explicitly related to the local government revenue structure. The Scandinavian local governments have general competence, which means that they can undertake whatever tasks they want unless another layer of government has the responsibility by law. However, this opportunity is rather limited because mandatory tasks take most of their revenue. As stated earlier in this paper, central government uses many different mechanisms to make sure that local governments fulfil these tasks in an appropriate way according to national norms and rules. The number of national laws that regulate local government administration and local service provision, for instance, has increased dramatically (Fimreite et al., 2004). Nationally determined tasks are economically burdensome and most available revenues are tied up to accomplish these mandatory tasks. Consequently, many local governments have poor economic capacity to engage in other issues than in these tasks.

This is the situation that makes many local politicians and decision-makers frustrated because they are constantly searching for new sources of income. However, this is not easy ${ }^{15}$. Local governments in Norway derive their income mainly from three sources: taxation, transfers from central government, and various types of fees. The opportunity to affect the amount of money from these sources is restricted due to the regulations decided on by national politicians. The rate of taxation is regulated by the parliament, ${ }^{16}$ transfers from government are partly regulated according to "objective" norms and partly as earmarked grants, and many of the fees are also regulated by central authorities ${ }^{17}$. According to Østerrud and Selle, "on average, 90 percent of municipal incomes are decided, one way or the other, at the central level" (Østerrud \& Selle, 2006: 4).There is, however, one option that local governments are increasingly aware of, and that is to increase taxes as the main revenue. Even though the tax rate is regulated by parliament, more jobs (and thereby taxpayers) in a municipality will improve the income base for local government. A business-friendly policy and facilitating more collaboration with private actors are often regarded as necessary remedies to succeed with economic development policy in a municipality. Many CEOs of municipalities are, of course, aware of this and argue accordingly when the resources are scarce and the decision-makers need strong priorities. They will use phrases like 'local government expenditure for the benefit of more revenue,18 when they argue in favour of expensive development policies instead of accepting various 'carrots' from central authorities which aim at various welfare projects. 
Since these projects sometimes imply 'revenue for the benefit of more local government expenditure ${ }^{, 19}$, the projects will have a difficult way through the prioritisation process in the municipality (Lyngstad, 1997). The argument will be that a successful economic policy is crucial because it creates jobs thereby increasing taxes. The decreasing scope of action for local decision-makers (due to poor economy) favours therefore special paradigms in local politics. These paradigms often emphasise and approve economically motivated development policies in order to ensure growth in a municipality. Explicitly, more focus on development policy is justified because it will presumably create jobs, more taxes thereby increasing the scope of action for local politicians in the future. This way of thinking makes way for new policy fields in the grey areas between politics, economic market, and civil society. This being the case, the climate is good for establishing local growth machines (Logan \& Molotch, 1987) by using partnerships and informal governance processes ${ }^{20}$.

\section{Concluding Summary}

The debate about rationales for local government and democracy coincides with a political climate that has for some decades questioned the state's role in allocating 'goods and burdens' in society. Under the influence of neo-liberal thinking and NPM mechanisms, the public sector's role in collective problem solving has been challenged. However, recent developments and discourses seem to re-establish the state's role in society. The financial crisis is obviously the best example. The reassessment of the political arena as crucial for allocating collective goods is also obvious within political and social sciences. Titles like "Bringing the State back in" (Evans et. al., 1985) and "Rolling back the Market" (Self, 2000) illuminate examples of this interest in reassessing the relationship between public, private and civil sectors in society. The general governance debate should be understood in light of this backdrop.

This paper addresses a smaller and more specific part of the polity, changes in the relationship between central and local levels of public decision-making, and, in particular, how changes in policy fields affect rationales for local government and democracy. Centralisation and governance tendencies are expanding, and the increase in governance and network activities at the local level must be seen in relation to the decrease in the vertical autonomy of local decision-makers in the traditionally important field of welfare policies. The retreat of politics in one local policy field seems to make room for political participation in other fields. Primarily, these are policy fields dealing with cultural activities, leisure issues, transport, industrial and business policies - policy fields where interference from central authorities are more unusual. In short, all policies aiming at growth and development in the community will probably be more and more in the forefront of local interest. Not only because the local autonomy is relatively higher in these areas, but also because the need for more revenues in local politics is constant, and 
political actors turn to these policies hoping to increase the local government's revenue base. Both elected and non-elected political actors are involved. Elected politicians partly because they must legitimate their political engagements in the areas and issues where their engagements have impacts and "local councillors search high and low for new ways that may revitalise their roles as important political actors and decision makers in local government" (Hansen, 2001: 120). Developmental policies are examples of policy fields where political vigour will have high visibility in the public. In addition, non-elected political actors from civil society and local business will be inclined to engage in these kinds of policies and decision-making processes partly for the same reasons as elected politicians, and also because they will often invest interest in the outcome (e.g., various business-friendly policies). Thus, a limited local influence on (re)distributive policies paves the way for more focus on developmental policies where networking and governance processes are more appropriate. However, more empirical research is needed. The study focusing on the commitment and the time used by mayors and CEOs in the municipalities in relation to developmental, distributive and redistributive policies would be of great interest as a background for more analysis of the democratic implications of contemporary changes in local decision-making.

Contemporary developments make it necessary to question whether the 'traditional' arguments, leading to substantial discretion for local government in welfare issues (the democratic argument and the instrumental "tailor-sewing" argument), are important and 'close to reality'. The democratic argument, favouring local decision-making based on the local freedom values, seems to lose value, and more weight is given to the national equality values in service deliverance on behalf of central government. The instrumental argument seems to be redefined on expediential grounds on behalf of national politicians. In any case, the arguments are under great pressure, and justifications for local government and decision-making need to be complemented in a way that they take the focus away from welfare issues towards more economic and developmental policies where governance networks attain more importance. A reconsideration of rationales for local decision-making must also take into account another democratic infrastructure (the influence of governance networks) that may challenge the traditional parliamentary chain of government. Due to the central interference in the traditionally important local policy fields, the decreased vertical autonomy may paradoxically vitalize local decision-making in the horizontal dimension of local autonomy. Political centralisation in one policy field accommodates governance networks to engage in new policy arenas where the scope of action is substantial, and the relevance of political participation at the local level is thus re-established.

There is, however, a somewhat paradoxical fact that local election campaigns still focus on distributive and redistributive policies. Why do they do this if the local 
politicians' scope of action is diminishing in these fields? One answer may be that being loyal implementers of the nationally designed policies, local actors are in charge of a substantial amount of money. This is prestigious even though the discretion is rather low. Research shows that most of the issues in local elections originate from the local context (Jacobsen and Skomeland 2008), but many of the issues are characterised by political centralisation and administrative decentralisation as mentioned earlier in this paper. Besides, the space for the locally conducted policy is big enough to make engagement and participation in welfare politics interesting. A White Paper from Norway accepts, for instance, that the scope of local action has decreased, however, "there are still a lot of areas for local policy-making", "which seems that central instructions are not mandatory", and "the local governments have space for innovation and development" (my translation) (NOU, 2005: 6, 11). Therefore, the argument is that even though the scope of action has been reduced for local politicians during the last few decades, there are still many policy arenas and policy fields in which citizens will find it significant and satisfying to participate or become involved. This is probably true today. But if the contemporary developments, pointed out in this paper and supported by the Norwegian 'Power and Democracy' project, continue (judicialisation of welfare policies and more decision-making based on governance processes), the reconsideration of justifications for local selfgovernment and local decision-making seems necessary, at least in Norway, but possibly also in other unitary states with a comprehensive welfare sector. Such a reconsideration must imply more focus on power relations and democratic implications of growing governance networks at the local level of public policy.

\section{Notes}

1 In a newly published article Jacobsen (2009) - with reference to new research about Norwegian municipalities - is questioning whether these and other trends is hollowing out local authorities as conventional wisdom seems to assert. He maintains, however, that in some settings networking and horizontal governance structures may be growing.

${ }^{2}$ By an expediential justification "is meant those arguments that value an activity or institution only to the extent that it serves the purpose of another institution or activity. In the context of local government, this is, for example, to justify the institution as a means to secure efficient delivery of services on behalf of central government" (Chandler, 2008: 355).

${ }^{3}$ It is It is also a fact that many public services within the welfare sector were first introduced and implemented in municipalities and then launched at national level.

${ }^{4}$ See http://www.skl.se/artikel.asp?A $=58868 \& C=370$.

${ }^{5}$ See http://www.regjeringen.no/nb/dep/krd/tema/kommuneokonomi/finansiering-avsektoren-samlet-herunder.html?id $=552048$.

${ }^{6}$ A white paper in Norway uses a more sophisticated typology of local vertical autonomy (NOU 2005:6). The white paper identifies three aspects related to autonomy. First, the scope of action, that is the formal possibility to act. Second, the possibility to act, which is about the possibilities in practice. Third, the ability to act, which is about the ability to reach given objectives. 
7 This is a conclusion very much in line with the understanding asserted by The Norwegian Association of Local and Regional Authorities (KS).

8 There are, of course, many complementary theories analysing the democratic potentials of different decision-making structures. Sørensen and Tørfing (2009a) mention for instance elitedemocratic perspectives (Etzioni-Halevy, 1993), communitarianism (Sandel, 1996), associational democracy (Hirst, 1994), participatory governance ((Fung \& Wright 2003), discursive democracy (Dryzek, 2000) and governance network theory (Rhodes 2000) as theories providing a supplement to the parliamentary chain of representative democracy.

9 The main conclusion in most of the analyses seems to be that seeking political power by influencing political decisions through the numeric-democratic channel is inadequate. Activity in "grey-zones" between public, private and civil sector is important to analyse if we want to understand decision-making processes. Informal governance-processes outside the overt decision-making system seem to have substantial impact on policy outcome. This is also the case on local level. Many studies show that actors without any democratic mandate from local elections have great influence on local policy-making and thus might represent a democratic problem (for example DiGaetano, 1997; Dowding, 2000; Harding, 1997; Lyngstad, 2000) while other studies have a more positive assessment of the democratic potentials (Andersen, 2004). 10 We should of course notice that the concept 'governance network' is not completely describing new phenomenon in political and administrative science. Concepts like (neo)corporatism, policy networks, policy communities, iron triangles, segmentation and compartementalisation have been used to describe similar decision-making processes.

11 It should be noticed, however, that there has been a debate in the Scandinavian countries about the conclusions in the Norwegian "Power and Democracy" project (Andreassen, 2006; Selle, 2006; Røyseland, 2006) and whether there is a parallel development in other Scandinavian countries. At least the Danish project is a little more optimistic about the democratic implications of more decision-making in governance networks. The Danish study seems to conclude that there has not been a systematic weakening of the parliamentary chain of governance in Denmark (Christiansen \& Togeby, 2006) even though this conclusion is contested as well.

12 These books are: Benz \& Papadopoulos (eds.) (2006), Djelic \& Sahlin-Anderson (eds.) (2006), Marcusson \& Tørfing (eds.) (2007), and Sørensen \& Tørfing (eds.) (2007).

13 Petersons has a public-choice inspired focus on municipalities' competitive needs for economic growth, and how economic and fiscal structures in local government results/favours developmental policies.

${ }^{14}$ Central government seems to appreciate this development, and is looking for good examples of successful partnerships. An indication of the interest in this issue is the fact that the Norwegian Research Council has initiated a research-program focusing partnerships, governance and developmental policies.

15 Based on OECD Economic Studies a Green paper conclude that the degree of fiscal autonomy is substantially more restricted in Norwegian municipalities compared to other European countries (NOU, 2005: 6, 139).

16 Ulike many other countries, local city councils in Norway have few opportunities to decide the tax rate (except for property tax). However, there seems to be a trend among some political parties to open up for more discretion for local governments in this issue.

17 In all the sectors (technical sector, welfare services, the school system and kindergartens) there are nationally regulations delimiting the degree of discretion for local governments to increase the fees.

${ }^{18}$ In the Norwegian language 'utgift til inntekts ervervelse'.

${ }^{19}$ In the Norwegian language 'inntekts til utgifts ervervelse'. In the budgetary debate these two phrases are often used by CEOs in the municipalities. 
${ }^{20}$ For an example of how partnerships and governance networks are impacting local policy, see for instance Sørensen and Torfing (2000).

\section{References}

Andersen, H. T. \& Van Kempen, R. (2001) Governing European Cities. Social fragmentation, social exclusion and urban governance (Farnham, UK: Ashgate).

Andersen, O. J. (2004) Public-Private Partnerships: Organizational Hybrids as Channels for Local Mobilization and Participation?, Scandinavian Political Studies, 27 (1), pp. 1-21.

Andreassen, T. A. (2006) Tilleggdemokratiets betydning - om den parlamentariske styringskjedens utilstrekkelighet i velferdsstaten, Tidsskrift for samfunnsforskning, 47 (3), pp. 439-463.

Ansell, C. K. (2008) Governance and Democracy: Comparing National, European and International Experiance, European Political Science, 7 (4), pp. 460-471.

Baldersheim, H., Bernt, J. F., Kleven, T. \& Rattsø, J. (eds) (1997) Kommunalt selvstyre $i$ velferdsstaten (Otta: Tano Ashehoug).

Benz, A. \& Papadopoulos, Y. (eds) (2006) Governance and Democracy: Comparing National, European and International Experiences (New York: Routledge).

Bogason, P. (2000) Public Policy and Local Governance. Institutions in a Post-Modern Society (Cheltenham, UK: Edward Elgar).

Castell, M. (1978) City, Class and Power (London: MacMillan).

Chandler, J. A. (2008) Liberal Justifications for Local Government in Britain: The Triumph of Expediency over Ethics, Political Studies, 56 (2), pp. 355-373.

Christensen, T. \& Lægreid, P. (eds.) (2007) Transcending New Public Management. The Transformation of Public Sector Reforms (Aldershot: Ashgate).

Christiansen, P. M. \& Togeby, L. (2006) Power and Democracy in Denmark: Still a Viable Democracy?, Scandinavian Political Studies, 29 (1), pp. 1-24.

Craw, M. (2006) Overcoming City Limits: Vertical and Horizontal Models of Local Redistributive Policy Making, Social Science Quarterly, 82 (2), pp. 361-379.

Dahl, R. A. (1961) Who Governs? Democracy and Power in an American City (New Haven \& London: Yale University Press).

DiGaetano, A. (1997) Urban governing alignments and realignments in comparative perspective. Developmental politics in Boston, Massachusetts and Bristol, England, 19801996, Urban Affairs Review, 32 (6), pp. 840-870, doi: 10.1177/107808749703200605.

Djelic, ML. \& Sahlin-Anderson, K. (eds.) (2006) Transnational Governance: Institutional Dynamics of Regulation (Cambridge, UK: Cambridge University Press).

Dowding, K (2000) Explaining urban regimes, International Journal of Urban and Regional Research, 25 (1), p. 7.

Dryzek, J. S. (2000) Deliberative Democracy and Beyond (Oxford: Oxford University Press), doi: 10.1093/019925043X.001.0001.

Elkin, S. L. (1985) Twentieth century urban regimes, Journal of urban affairs, 7 (2), pp. 11-28.

Elkin, S. L. (1987) City and Regime in the American Republic (Chicago: University of Chicago Press).

Etzioni-Halevy, E. (1993) The Elite Connection: Problems and Potential of Western Democracy (Cambridge: Polity Press).

Evans, P. B., Rueschemeyer, D. \& Skocpol, T. (eds.) (1985) Bringing the State Back In (Cambridge: Cambridge University Press).

Fimreite, A. L., Flo, Y., Tranvik, T. \& Aars, J. (2004) Tillitsforboldet mellom forvaltningsnivåene. Sentrale aktorers holdninger og oppfatninger til kommunene (Bergen: Rokkansenteret) 
Fimreite, A. L, Flo, Y., Selle, P. \& Tranvik, T. (2007) Når sektorbåndene slites, Tidsskrift for samfunnsforskning, 48 (2), pp. 165-193.

Fimreite, A. L., Ynge, F. \& Tranvik, T. (2002) Lokalt handlingsrom og nasjonal integrasjon. Kommuneideologiske brytninger $i$ Norge $i$ et historisk perspektiv. Makt og demokratiutredningen. Rapport nr. 50. Unipub.

Fung, A. \& Wright, E.O. (eds.) (2003) Deepening Democracy: Institutional Innovations (London: Verso).

Grønlie, T. (1987) Velferdskommune og utjevningsstat. 1945-1970, In: Næss, H. E., Hovland, E., Gronlie, T., Baldersheim, H. \& Danielsen, R., Folkestyre $i$ by og bygd. Norske kommuner gjennom 150 ar (Oslo: Universitetsforlaget).

Hansen, K. (2001) Local Councillors: Between local 'government' and local 'governance', Public Administration, 79 (1), pp. 105-123.

Hansen, T., Sissel, H. \& Klausen, J. E. (2000) Stortinget som lokalpolitisk aktør. NIBRs Plussserie, no.3. (Oslo: NIBR).

Harding, A. (1997) Urban regimes in a Europe of the cities, European Urban and Regional Studies, 4 (4), pp. 291-314, doi: 10.1177/096977649700400401.

Haugsvær, S. (2003) Maktutredningens hovedkonklusjoner (Nyhetsbrev 26.08.03).

Hirst, P. (1994) Associative Democracy. New Forms of Economic and Social Governance (Cambridge: Polity Press).

Hunter, F. (1953) Community Power Structure (Chapel Hill: Univ. of North Carolina Press).

Jacobsen, D. I. \& Skomeland, A. S. (2008) Regionavisenes dekning av kommune og fylkestingsvalget 2007 - belyst gjennom dekninga i avisene Agderposten og Fedrelandsvennen, Norsk Statsvitenskaplig Tidskrift, 24 (4), pp. 307-327.

Jacobsen, D. I. (2009) A Tragedy of the Councils? Exploring the Hollowing-Out Hypothesis the Case of Norwegian Local Authorities, Lex localis - Journal of Local Self-Government, 7 (3), pp. 221-242.

John, P. (2001) Local Governance in Western Europe (London, Thousand Oaks: Sage Publications).

Kjær, A. M. (2004) Governance (Cambridge: Polity Press).

Kjær, A. M. (2009) Governance and the urban bureaucracy, In: Davies, J. S. \& Imbroscio, D. L. (eds.) Theories of Urban Politics (London: Sage).

Kjellberg, F. (1991) Kommunalt selvstyre og nasjonal styring. Mot nye roller for kommunene. Norsk statsvitenskaplige tidsskrift, 7 (1), pp. 45-63.

Klijn, E. \& Skelcher, C. (2007) Democracy and governance networks: Compatible or not? Public Administration, 85 (3), pp. 587-608.

Kohler-Koch, B. (2006) Research on EU Governance: Insight from Stock-Taking Exercise. Connex Newsletter 3, pp. 4-6.

Kosonen, P. (2001): Globalization and the Nordic Welfare States, In: Sykes, R., Palier, B. \& Prior, P. (eds.) Globalization and European Welfare States (Hampshire: Palgrave Macmillan).

Lindblom, C. (1977) Politics and Markets: The world's political economic systems (New York: Basic Books).

Logan, J. \& Molotch, H. (1987) Urban Fortunes: The Political Economy of Place (Berkeley: University of California Press).

Lowi, T. J. (1964) American Business, Public Policy, Case Studies, and Political Theory, World Politics, 16 (4), pp. 677-715.

Lyngstad, R. (1997) Den kommunale tenkemåte. Ein case-studie av makt og innverknad $i$ ein norsk kommune - belyst gjennom ein prioriteringskonflikt mellom tre kommunale utbyggingsprosjekt. Dr. philos-avhandling (Høgskolen i Bodø).

Lyngstad, R. (2000) Regimeteori på norsk. Ei drøfting av regimeteori og forståinga av makt og innverknad i norske kommunar, Norsk Statsvitenskaplig Tidsskrift, No. 4. 
March, J.G. \& Olsen, J.P. (1989) Rediscovering Institutions: The Organizational Bases of Politics (New York: The Free Press).

Marcussen, M. \& Tørfing, J. (eds.) (2007) Democratic Network Governance in Europe (Hampshire: Palgrave MacMillan).

Marshall, T.H. (1964) Class, Citizenship and Social Development (Chicago: University Press).

Mill, J.S. (1975) Essay on Liberty, In: Wollheim, R. (ed.) John Stuart Mill: Three Essays (Oxford: Oxford University Press).

Molotch, H. L. (1976) The city as a growth machine, American Journal of Sociology. 82 (2), pp. 309-332.

Mossberger, K. (2009) Urban regime analyses, In Davies, J. S. \& Imbroscio, D. L. (eds) Theories of Urban Politics (London: Sage Publications).

NOU (2005) 6 Samspill og tillit. Om staten og lokaldemokratiet.

Olsen, J. P. (1978) Politisk organisering (Oslo: Universitetsforlaget).

Olsen, J. P. (2009) Change and continuity: an institutional approach to institutions of democratic government, European Political Science Review, 1 (1), pp. 3-32, doi: $10.1017 / \mathrm{S} 1755773909000022$.

Østerud, Ø. \& Selle, P. (2006) Power and Democracy in Norway: The Transformation of Norwegian Politics, Scandinavian Political Studies, 29 (1), pp. 25-46.

Østerud, Ø., Engelstad, F. \& Selle, P. (2003) Makten og demokratiet. En sluttbok fra Makt- og demokratiutredninga (Oslo: Gyldendal Akademisk)

Papadopoulos, Y. (2007) Problems of Democratic Accountability in Network and Multilevel Governance, European Law Journal, 13 (4), pp. 469-486.

Papadopoulos, Y. (2009) Accountability and Multi-Level Governance: More Accountability, Less Democracy?, Paper presented at the 21 ${ }^{\text {st }}$ IPSA World Congress of Political Science 12 - 16 July, 2009, Santiago, Chile.

Peterson, P. E.(1981) City Limits (Chicago: University of Chicago Press).

Pickvance, C. (1995) Marxist theories of urban politics, In: Judge, D., Stoker, G. \& Wolman, H. (eds) Theories of Urban Politics (London: Sage).

Pierre, J. (1998) Public-Private Partnerships and Urban Governance: Introduction, In: Pierre, J. (ed.) Partnerships in Urban Governance. European and American Experience (London; MacMillan Press Ltd.).

Pierre, J. (ed.) (2000) Debating Governance: Authority, Steering and Democracy (Oxford: Oxford University Press).

Pierre, J. \& Peters, B. G. (2000) Governance, Politics and the State (Hampshire: Palgrave Macmillian).

Pierre, J. (2005) Comparative Urban Governance: uncovering complex causalities, Urban Affairs Review, 40 (4), pp. 446-462.

Polsby, N. (1960) How to Study Community Power: The Pluralist alternative, Journal of Politics, 22 (3), pp. 474-484.

Rhodes, R.A.W. (2000) Governance and Public Administration, In: Pierre, J. (ed.) Debating Governance: Authority, Steering and Democracy (Oxford: Oxford University Press).

Rhodes, R.A.W. (1997) Understanding Governance. Policy Networks, Governance, Reflexivity and Accountability (Berkshire, UK: Open University Press).

Røiseland, A. (2006) Demokratiets infrastruktur i forfall?, Tidskrift for samfunnsforskning, 47 (3), pp. 427-435.

Rokkan, S. (1966) 'Norway: Numerical Democracy and Corporate Pluralism, In: Dahl, R.A. (ed.) Political Oppositions in Western Democracies (London: Yale University Press).

Sandel, M. J. (1996): Democracy's Discontent - America in Search of a Public Philosophy (Cambridge, MA: Harvard University Press). 
Sharp, L. J. (1970) Theories and Values of Local Government, Political Studies, 18 (2), pp. 153174.

Scharpf, F.W. (1999) Governing in Europe (Oxford: Oxford University Press).

Self, P. (2000) Rolling Back the Market. Economic Dogma and Political Choice (Hampshire: Palgrave Macmillan).

Selle, P. (2006) Forfall eller foranding?, Tidskrift for samfunnsforskning, 47 (3), pp. 451-463.

Sellers, J.M. \& Lidstrøm, A. (2007) Decentralization, Local Government, and the Welfare State, Governance - An International Journal of Policy and Administration, 20 (4), pp. 609-632.

Sørensen, E. \& Torfing, J. (2000) Skanderborg på landkortet - et studie af lokale styringsnetvark og politisk handlekraft (København: Jurist- og økonomforbundets Forlag).

Sørensen, E. \& Tørfing, J. (2009a) Making governance networks effective and democratic through metagovernance, Public Administration, 87 (2), pp. 234-258.

Sørensen, E. \& Tørfing, J. (2009b) The European Governance Debate, Paper prepared for the $21^{\text {st }}$ IPSA World Congress of Political Science 12 - 16 July, 2009, Santiago, Chile.

Sørensen, E. \& Tørfing, J. (2005) The Democratic Anchorage of Governance Networks, Scandinavian Political Studies, 28 (3), pp. 195-218.

Sørensen, E. \& Tørfing, J. (eds.) (2007) Theories of Democratic Governance (Hampshire: Palgrave Macmillan).

Stone, C. (1980) Systemic power in community decision making: a restatement of stratification theory, American Political Science Review, 74 (4), pp. 978-990.

Stone, C. (1989) Regime Politics: Governing Atlanta, 1946-1988 (Lawrence: University Press of Kansas).

Stone, C. (1993): Urban regimes and the capacity to govern: a political economy approach, Journal of Urban Affairs, 15 (1), pp.1-28.

Stone , C. (2009) Who is governed? Local citizens and the political order of cities, In: Davies, J. S. \& Imbroscio, D. L. (eds.) Theories of Urban Politics (London: Sage Publications).

Tiebout, C. M. (1956) A pure theory of local expenditure, Journal of Public Economy, 64, p. 416. Vabo, S. (ed.) (1998) Nasjonale ideologier bak endringene i kommunesektoren (Novemus: NIBR). 